\title{
Innovation Fungi, Toxins Foundation in Maize Grains Collected from Various Iraqi Marketplaces
}

\author{
Intesar Ali Mezeal, Moayad Salih hussin and Shaimaa N. Mizil \\ Department of Biology, College of Science, Mustansiriyah University, Iraq.
}

\begin{abstract}
Maize stays inimitable of uppermost cornflakes used global by way of infrequent considerable on behalf of footing of unrelated products, like tortillas, cash, bars, cookies, pizzas. Substantial loss in maize production stands infection by dint of Mycological pollution. Determination of examination stayed toward separate besides executive aflatoxin equal fashionable maize seeds examples. Mycological contamination initiate fashionable completely stowed examples poised commencing selected families fashionable Iraqi government. Mycotoxin formation via cloistered fungi consequently dignified by thin layer chromatography method. seven diverse molds inaccessible as of $\mathbf{8 8}$ maize examples inspected aimed at Mycological pollution recognized .Many mycotoxins remained empirical fashionable recent pursuit excluding aflatoxin B1 besides fumonisin B1 .

Keywords: Maize, Mycological pollution, toxins, thin layer chromatography, Iraq.
\end{abstract}

*Correspondence: intesarali664@uomustansiriyah.edu.iq

(Received: 05 August 2018; accepted: 12 September 2018)

Citation: Intesar Ali Mezeal, Moayad Salih hussin and Shaimaa N. Mizil, Innovation Fungi, Toxins Foundation in Maize Grains Collected from Various Iraqi Marketplaces, J Pure App/ Microbiol., 2018; 12(4):2175-2181. http://dx.doi.org/10.22207/JPAM.12.4.56

(C) The Author(s) 2018. Open Access. This article is distributed under the terms of the Creative Commons Attribution 4.0 International License which permits unrestricted use, sharing, distribution, and reproduction in any medium, provided you give appropriate credit to the original author(s) and the source, provide a link to the Creative Commons license, and indicate if changes were made. 


\section{INTRODUCTION}

Maize (Zea mays) cornflakes produce refined lengthily concluded biosphere consumes maximum making amongst completely cornflakes (Kogbe and Adediran, 2003). Maize remains domineering cornflakes by way of substance of regime besides nutrition. Frequent molds thoughtful seeds pathogens fashionable turf otherwise storage, manufacturing frequent types of annihilation besides mycotoxin effluence (Logrieco et al., 2003; Torres et al., 2006). Fungal kinds usually invent fashionable kept particles be present Fusarium, Aspergillus and Penicillium, plentiful of by capabilities of generating toxins (Christensen, 1987; Lacey, 1989). Development of molds container remain ostentatious through dampness gratified of invention (Giorni et al.,2009; Hell et al., 2000), temperature besides stowage period. indications chief toward vertical of classifying molds types fashionable stowed grain, by unusual discussion aimed at mycotoxin ones, advanced container stand possible risk aimed at persons besides visceral wellbeing.

Mycotoxins describe diverse collection of lower molecular mass biochemical composites, that recent biological inactivity, twisted trendy subordinate breakdown via selected fungi types, that regularly drive toward Fusarium, Aspergillus, Penicillium. Subordinate metabolites obligate dangerous action collected individuals, naturally, that container remain organization by way of common pollutants interested in feedstuff besides nutrition handcuffs. Precise toxins container remain carcinogenic (fumonisins, FB, Collection 2B: conceivable cancer causing aimed at individuals), cancer causing and teratogen (ochratoxin A, OTA, Collection $2 \mathrm{~B}$ ), carcinogenic, mutation causing and teratogen (aflatoxin B1, AF, Collection 1; aflatoxin M1, Collection 2B), (Bryden, 2002). Mycotoxins harvest fashionable soil pro harvest, harvest, powerful, besides storage phases, conditions able to cumulative fungus resultant in mycotoxin formation (Candlish et al., 2001). Contamination risk via mycotoxins authoritative food courtesy apprehension aimed at grains besides extra field harvests. Mycotoxins touching mueslis remain cautious toward remain of greater significance biosphere done designed for humanoid beings (Bhat et al., 2000; Bryden, 2007).

\section{Supplies and Procedure Examples gathering}

Whole ninety stowed maize grains collected commencing various Iraqi Marketplaces, grains remained registered, enclosed trendy sterile baggage, enthused toward test center then earmarked in $4^{\circ} \mathrm{C}$.

\section{Separation}

Connected fungi quarantined as of saved maize samples. Samples decontaminated, eroded fashionable 2 alterations decontaminated disinfected water. Maize samples discolored dehydrated trendy amongst disinfected filter papers, cultivated going on sterilized PDA(10 grains in dishes). Four duplicates dishes each media castoff every example besides hatched at $30^{\circ} \mathrm{C}$. Aimed at fife days. Developed molds uncovered toward ID via help of resultant references (Booth,1971; Ellis,1979; Pitt,1979; Domsch et al.,1980; Kozakiewicz,1989; Klich,2002; Samsonet al.,1995; Samson et al., 2002).

\section{In Maize examples Inspection of B1 and G1}

Aflatoxins uninvolved as of Maize tasters discussing toward process characterized via (Schuller et al.,1983). 25 gram of all Maize example remained supplementary to (250) $\mathrm{ml}$ tapering hipflask containing (25) $\mathrm{ml}$ disinfected water then (50) $\mathrm{ml}$ chloroform. hipflasks shocked meant for 30 minutes via shaker, suspensions filtered. following chloroform excerpts disinfected execution to (Takeda et al., 1979) , Elutes faded toward aridity on vapor bath. All balance stayed re-dissolved in (1) $\mathrm{ml}$ chloroform, Aflatoxins tested on (TLC) sheet, penetrated by silica gel, all sample extract cover aflatoxins stayed loaded in silica gel dishes standard aflatoxins B1, G1. dishes well-known fashionable a glass jar cover chloroform-acetone (9:1) v/v by way of evolving in credit. Aflatoxins restrained by way of nominated via (Shannon et al., 1983; FAO,2004). Magnitudes stayed accomplished done fluorescence at (370) $\mathrm{nm}$.

Investigation about aflatoxins produced by Aspergillus flavus

Method expected in present inspection approved out discussing to (A.O.A.C., 1984). (1) $\mathrm{ml}$ aliquot from spore suspension (10-6) used to infect (250) $\mathrm{ml}$ tapering flask cover (100) $\mathrm{ml}$ from Medium (Czapek's Doxtros Agar), flask hatched to ten days in dark at $30^{\circ} \mathrm{C}$. in end of gestation 
Index 1. Toxins in Maize samples

\begin{tabular}{|c|c|c|}
\hline $\begin{array}{l}\text { Maize } \\
\text { examples }\end{array}$ & $\begin{array}{c}\text { AFB1 ( } \mu g / k g \\
\text { dry wt.) }\end{array}$ & $\begin{array}{c}\text { AFG1 ( } \mu \mathrm{g} / \mathrm{kg} \\
\text { dry wt.) }\end{array}$ \\
\hline CB1 & 391 & 80 \\
\hline CB 2 & 30 & 0 \\
\hline CВ 3 & 358 & 150 \\
\hline CB 4 & 0 & 0 \\
\hline CB 5 & 98 & 50 \\
\hline CB 6 & 100 & 100 \\
\hline CB 7 & 245 & 700 \\
\hline CB 8 & 0 & 0 \\
\hline CB 9 & 685 & 780 \\
\hline CB 10 & 745 & 700 \\
\hline CB 11 & 145 & 100 \\
\hline CB 12 & 0 & 0 \\
\hline CB 13 & 0 & 0 \\
\hline CB14 & 215 & 300 \\
\hline CB15 & 70 & 40 \\
\hline CB16 & 90 & 0 \\
\hline CB17 & 790 & 750 \\
\hline CB 18 & 445 & 0 \\
\hline CB19 & 0 & 0 \\
\hline CB20 & 40 & 80 \\
\hline CB21 & 155 & 90 \\
\hline CB22 & 30 & 40 \\
\hline C B23 & 0 & 0 \\
\hline CB24 & 300 & 380 \\
\hline CB25 & 280 & 40 \\
\hline CB26 & 0 & 0 \\
\hline CB27 & 80 & 40 \\
\hline CB28 & 700 & 80 \\
\hline CB29 & 0 & 0 \\
\hline CB30 & 700 & 0 \\
\hline CB31 & 40 & 200 \\
\hline CB32 & 100 & 80 \\
\hline CB33 & 800 & 380 \\
\hline CB34 & 0 & 0 \\
\hline CB35 & 0 & 40 \\
\hline CB36 & 100 & 0 \\
\hline CB37 & 380 & 380 \\
\hline CB38 & 600 & 40 \\
\hline CB39 & 800 & 760 \\
\hline CB40 & 60 & 0 \\
\hline CB41 & 400 & 400 \\
\hline CB42 & 0 & 0 \\
\hline CB43 & 380 & 0 \\
\hline CB44 & 100 & 750 \\
\hline CB45 & 0 & 0 \\
\hline CB46 & 180 & 40 \\
\hline CB47 & 40 & 80 \\
\hline CB48 & 400 & 0 \\
\hline CB49 & 0 & 0 \\
\hline CB50 & 0 & 0 \\
\hline
\end{tabular}

Index 1. continues

\begin{tabular}{|c|c|c|}
\hline $\begin{array}{l}\text { Maize } \\
\text { examples }\end{array}$ & $\begin{array}{l}\text { AFB1 ( } \mu \mathrm{g} / \mathrm{kg} \\
\text { dry wt.) }\end{array}$ & $\begin{array}{c}\text { AFG1 ( } \mu \mathrm{g} / \mathrm{kg} \\
\text { dry wt.) }\end{array}$ \\
\hline CB51 & 700 & 80 \\
\hline CB52 & 300 & 60 \\
\hline CB53 & 100 & 40 \\
\hline CB54 & 80 & 0 \\
\hline CB55 & 0 & 40 \\
\hline CB56 & 100 & 80 \\
\hline CB57 & 0 & 0 \\
\hline CB58 & 0 & 0 \\
\hline CB59 & 0 & 660 \\
\hline CB60 & 500 & 80 \\
\hline CB61 & 120 & 400 \\
\hline CB62 & 80 & 0 \\
\hline CB63 & 0 & 0 \\
\hline CB64 & 40 & 80 \\
\hline CB65 & 0 & 0 \\
\hline CB66 & 0 & 0 \\
\hline CB67 & 80 & 100 \\
\hline CB68 & 200 & 100 \\
\hline CB69 & 0 & 0 \\
\hline CB70 & 90 & 0 \\
\hline CB71 & 540 & 40 \\
\hline CB72 & 30 & 660 \\
\hline CB73 & 0 & 0 \\
\hline CB74 & 0 & 0 \\
\hline CB75 & 80 & 100 \\
\hline CB76 & 0 & 0 \\
\hline CB77 & 90 & 200 \\
\hline CB78 & 645 & 0 \\
\hline CB79 & 750 & 800 \\
\hline CB80 & 0 & 0 \\
\hline CB81 & 55 & 0 \\
\hline CB82 & 30 & 0 \\
\hline CB83 & 800 & 765 \\
\hline CB84 & 90 & 60 \\
\hline CB85 & 755 & 300 \\
\hline CB86 & 0 & 0 \\
\hline CB87 & 200 & 0 \\
\hline CB88 & 365 & 460 \\
\hline CB89 & 0 & 0 \\
\hline CB90 & 335 & 0 \\
\hline
\end{tabular}

Maximum concentration of (AFB1) verified by (CB33,CB39) 800 ( $\mu \mathrm{g} / \mathrm{kg}$ dry wt.). while Maximum concentration of (AFG1) verified by (CB 10) 780 ( $\mu \mathrm{g} / \mathrm{kg}$ dry wt.). 
Table 2. Production Aflatoxins

\begin{tabular}{lll}
\hline Examples & AFB1 ( $\mu \mathrm{g} /$ & $\mathrm{AFG1}(\mu \mathrm{g} /$ \\
$\mathrm{kg}$ dry wt.) & $\mathrm{kg}$ dry wt.)
\end{tabular}

\begin{tabular}{|c|c|c|}
\hline Aspergillus flavus CB1 & 200 & 0 \\
\hline Aspergillus flavus CB 2 & 0 & 0 \\
\hline A Aspergillus flavus CB 3 & 180 & 200 \\
\hline Aspergillus flavus CB 5 & 0 & 0 \\
\hline Aspergillus flavus CB 6 & 100 & 0 \\
\hline Aspergillus flavus CB 7 & 60 & 400 \\
\hline Aspergillus flavus CB 9 & 400 & 380 \\
\hline Aspergillus flavus CB 10 & 320 & 440 \\
\hline Aspergillus flavus CB 11 & 100 & 0 \\
\hline Aspergillus flavus CB 14 & 80 & 300 \\
\hline Aspergillus flavus CB 15 & 0 & 0 \\
\hline Aspergillus flavus CB 16 & 0 & 0 \\
\hline Aspergillus flavus CB 17 & 380 & 380 \\
\hline Aspergillus flavus CB 18 & 300 & 0 \\
\hline Aspergillus flavus CB 20 & 0 & 60 \\
\hline Aspergillus flavus CB 21 & 100 & 0 \\
\hline Aspergillus flavus CB 22 & 0 & 0 \\
\hline Aspergillus flavus CB 24 & 80 & 100 \\
\hline Aspergillus flavus CB 25 & 200 & 0 \\
\hline Aspergillus flavus CB 27 & 0 & 0 \\
\hline Aspergillus flavus CB 28 & 380 & 0 \\
\hline Aspergillus flavus CB 30 & 200 & 0 \\
\hline Aspergillus flavus CB 31 & 0 & 60 \\
\hline Aspergillus flavus CB 32 & 0 & 40 \\
\hline Aspergillus flavus CB 33 & 200 & 140 \\
\hline Aspergillus flavus CB 36 & 0 & 0 \\
\hline Aspergillus flavus CB 37 & 180 & 200 \\
\hline Aspergillus flavus CB 38 & 300 & 0 \\
\hline Aspergillus flavus CB 39 & 380 & 380 \\
\hline Aspergillus flavus CB 40 & 0 & 0 \\
\hline Aspergillus flavus CB 41 & 300 & 160 \\
\hline Aspergillus flavus CB 43 & 200 & 0 \\
\hline Aspergillus flavus CB 44 & 0 & 300 \\
\hline Aspergillus flavus CB 46 & 80 & 0 \\
\hline Aspergillus flavus CB 47 & 0 & 0 \\
\hline Aspergillus flavus CB 48 & 180 & 0 \\
\hline Aspergillus flavus CB 51 & 380 & 20 \\
\hline Aspergillus flavus CB 52 & 200 & 0 \\
\hline Aspergillus flavus CB 53 & 0 & 0 \\
\hline Aspergillus flavus CB 54 & 0 & 0 \\
\hline Aspergillus flavus CB 56 & 0 & 0 \\
\hline Aspergillus flavus CB 59 & 0 & 380 \\
\hline Aspergillus flavus CB 60 & 280 & 60 \\
\hline Aspergillus flavus CB 61 & 40 & 380 \\
\hline Aspergillus flavus CB 62 & 0 & 0 \\
\hline Aspergillus flavus CB 64 & 0 & 80 \\
\hline Aspergillus flavus CB 67 & 80 & 0 \\
\hline Aspergillus flavus CB 68 & 100 & 0 \\
\hline Aspergillus flavus CB 70 & 0 & 0 \\
\hline Aspergillus flavus CB 71 & 200 & 0 \\
\hline
\end{tabular}

Table 2. Continues

\begin{tabular}{lcc}
\hline Examples & $\begin{array}{c}\text { AFB1 ( } \mu \mathrm{g} / \\
\text { kg dry wt.) }\end{array}$ & $\begin{array}{c}\text { AFG1 ( } \mu \mathrm{gg} / \\
\text { kg dry wt.) }\end{array}$ \\
\hline Aspergillus flavus CB 72 & 0 & 300 \\
Aspergillus flavus CB 75 & 20 & 0 \\
Aspergillus flavus CB 77 & 0 & 100 \\
Aspergillus flavus CB 78 & 380 & 0 \\
Aspergillus flavus CB 79 & 280 & 380 \\
Aspergillus flavus CB 81 & 0 & 0 \\
Aspergillus flavus CB 82 & 0 & 0 \\
Aspergillus flavus CB 83 & 380 & 380 \\
Aspergillus flavus CB 84 & 0 & 0 \\
Aspergillus flavus CB 85 & 300 & 100 \\
Aspergillus flavus CB 87 & 100 & 0 \\
Aspergillus flavus CB 88 & 200 & 300 \\
Aspergillus flavus CB90 & 160 & 0
\end{tabular}

Extreme concentration of (AFB1) standard by Aspergillus flavus CB 9 (400), while less concentration showing by Aspergillus flavus CB 75 (20). Approximately (AFG1) extreme concentration standard by Aspergillus flavus CB 10 (440), while fewer concentration obtainable by Aspergillus flavus CB 51 (20).

period, all flask filtered. excerpt conserved by way of nominated beforehand, by way of investigation of maize samples. Mycelia growing verbal as dry mass of mycelia mass collected after removal of aflatoxins, parching at $70^{\circ} \mathrm{C}$ for (1) day (Kane and Mullins,1973).

\section{RESULTS \& DISCUSSION Investigation for sequestered Fungi established in collected samples}

Values indicators exposed in Fig. 1 examination 90 example of grain kept in market places, composed randomly as of selected respects of Iraq. Sample alteration in stabilities of types of molds remote, occurrence ratio in examples, fraction of incidence in examples reviewed. Data available separation, ID of as (8) different fungi insulated by 90 maize examples observed to fungal pollution (Figure1).

Contamination occurs over insignificant quantities of microbes contaminating particle as working into storing starting harvest in handling, stowage apparatus or as of spores formerly existing in stowage buildings (RRI, 2006).

Colletotrichum, Aspergillus, Mucor, Rhizopus, Botryodiplodia and Macrophomina, 
existed designated by (Amadi and Oso, 1996). Talking on the way to (Alabi, 1989), highest shared stowage fungi (Penicilium, Aspergillus). Grains penetration via microbes remains a shared and predominant distinctiveness designated. (Amadi, 2002) consumed too designated certain fungi including, A. niger, R. stolonifer, A.solani, P. italicum and F.solanum tested grains.

Values in (Fig. 1) obtainable Aspergillus flavus standard extreme ratio of incidence (65.3) flowed by Aspergillus niger standard (64.4). While lowest ratio standard $(13.4 \%, 17.9)$ by Mucor, Rhizopus stolonifer correspondingly.

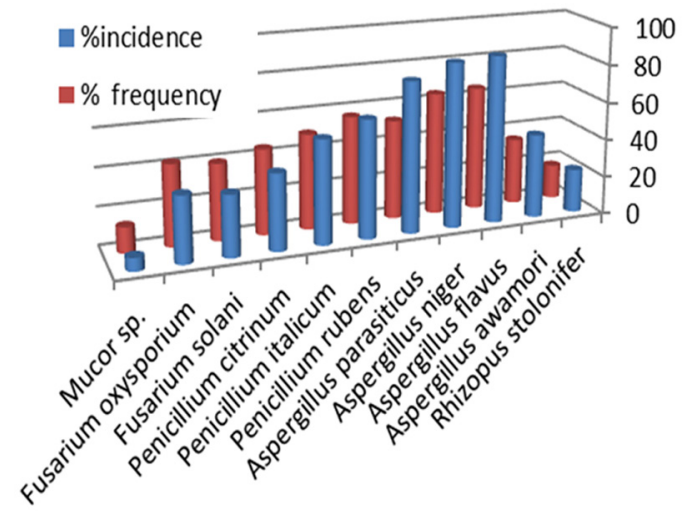

Fig. 1. Sequestered Fungi established in samples

Values shown Aspergillus flavus standard extreme ratio of frequency (87.9) ran by Aspergillus niger, Aspergillus parasiticus (86.5, 79.1 ) correspondingly. Although lowest ratio of frequency standard $(6.9 \%, 22.8)$ in Mucor, Rhizopus stolonifer correspondingly. Instructions on occurrence besides relative proportion of mycotoxigenic fungi very appreciated and compulsory for added working out on toxin producing fungi besides epidemiological denotation in maize. Frequent kinds of molds crop mycotoxins like Aspergillus, Penicillium are mycotoxigenic molds responsible for typical of mycotoxin contamination (Palumbo et al., 2008). Aptitude to yield AFB1, AFG1 in Maize

Values in(Index1) existing ability to harvest (AFB1) in grains recorded in (63) examples, while (AFG1) recorded in (50) examples.
Several previous detectives obligate designated cornflakes grain in growing as well as grape development characterize diet ecosystems that occupied via mycotoxigenic fungi, that biased via abiotic effects like typical temperature, relative humidity chiefly at a microclimate level besides storing conditions in frequent regions universally ecosphere (Castellari et al., 2010; Magan et al., 2010). Contamination might be due to protracted old-fashioned storing of presented corn in unsuccessful environmental disorder including great moisture besides temperature. Corn placed for extended time are extra vulnerable than again composed corn. Insects and rodents might also be donated to worsening the grains quickly, increasing corn mycoflora through lengthy period storing (Hussein and Brasel, 2001). So, practice of dressed agricultural does would discourage fungal growth besides mycotoxin production would be indispensable to reduction mycotoxin percentage in corn, corn products.

\section{Production Aflatoxins by Aspergillus flavus separates}

Values obtainable in (Index 2) refer to general variation of aflatoxins creation tangible among confirmed separates of Aspergillus flavus.

This is residual toward genomic modification aimed at strain, that replicated in quantity, reputation of formation via incurable metabolic paths in place of fungi confirmed variance (Liu et al., 2006). Aflatoxins have uppermost commanding visibly fashionable mycotoxins in cultivated crops. Aflatoxins created via several types as Aspergillus flavus, Aspergillus nomius (Varga and Samson, 2008). Previous instructions documented Aspergillus mycotoxigenic in saved crap, mycotoxins besides aflatoxins in varied applications (Pacinet al., 2009; Moreno et al., 2009). Nearby is a general propensity toward increase consumption of breakfast muesli besides cornflakes. Here is an inclusive preparation consumption of muted grains by mycotoxins is a endangerment for animal, human health, besides can lead to an important commercial. Instruction of the environs clue to fungi growing in storage and production of mycotoxins selected that grain dampness contented is unique of greatest important effects (Giorni et al., 2009). 


\section{REFERENCES}

1. A.O.A.C. Official Methods of Analysis of Association of Official Analytical Chemists14 th ed., AOAC, Chapter 26, 1984; pp: 447-484(Natural Poisons), Washington V.A.

2. Alabi RO. Mycology and National Development: Mobilization of Fungal Products for Life More Abundant. Inaugural Lecture. University of Ilorin, Ilorin, Nigeria. 1989.

3. Amadi JE. Studies on the mycoflora of sugarcane (Saccharum officinarum) seeds and their importance in the nursery. NISEB J. 2002; 2(1): 89-95.

4. Amadi JE, Oso BA. Mycoflora of Cowpea Seeds (Vigna unguiculata L.) and their effects on seed nutrient content and germination. Niger. J. Sci. 1996; 30: 63-69.

5. Bhat RV, Shetty HPK, Vasanthi S. Human and animal health significance of mycotoxin in sorghum. 2000; 18: 107-115.

6. Booth, C. The Genus Fusarium. 1st ed., 1971; p.237. Commonwealth Mycological Institute, Kew Surrey, England.

7. Bryden WL. Mycotoxins in the food chain, human health implications. Asia Pac J Clin Nutr, 2007; 16: 95-101.

8. Bryden, W.L. Mycotoxins in the food chain: Human health implications. Mutagenesis. 2002; 17: 471-481.

9. Candlish AAG, Pearson SM, Aidoo KE, Smith JE, Kell B, Irvine H. A. survey of ethnic foods for microbial quality and aflatoxin content. Food Addit. Contaminants, 2001; 18: 129-136.

10. Castellari, C., F. Marcos Valle, J. Mutti, L. Cardoso and $\mathrm{R}$ Bartosik. Toxigenic fungi in corn stored in hermetic plastic bags. Julius-Kühn-Archiv, 2010; 425: 501-504.

11. Christensen, C.M. Field and storage fungi. In: Beuchat $L R(E d)$ Food and Beverage Mycology. New York,Van Nostrand Reinhold, 1987; pp. 211232.

12. Domsch, K. W., Gams, W. and Anderson, T. H. Compendium of Soil Fungi, 1980; pp.1-859 Academic Press, London.

13. Ellis, M. B. More Dematiaceous Hyphomyctes. Commonwealth Mycological Institute, Kew, Surrey, UK. 1976.

14. FAO. FAO Food and Nutrition paper 81 World wide Regulations for Mycotoxins in Food and Feed in 2003, Rome, Italy, 2004.

15. Giorni, P., Battilani, P., Magan, N. Effect of solute and matric potential on in vitro growth and sporulation of strains from a new population of Aspergillus flavus isolated in Italy. Fungal Ecology. 2009; 1: 101-106.
16. Hell, K., Cardwell, K.F., Setamou, M., Poehling, H.M. The influence of storage practices on aflatoxin contamination in maize in four agroecological zones of Benin West Africa. Journal of Stored Products Research. 2000; 36: 365-382.

17. Hussein, S.H. and J.M. Brasel. Toxicity, metabolism and impact of mycotoxin on humans and animals. Toxicology, 2001; 167: 101-134.

18. Kane, B. E. and Mullins, J. T. Thermophilic fungi in a municipal waste compost system. Mycologia. 1973; 65: 1087-1100.

19. Klich, M. A. Identification of common Aspergillus species. 2002; p. 116. Utrecht, Netherlands: Centraalbureau voor Schimmelcultures.

20. Kogbe J.O.S. and JA Adediran. Influence of nitrogen, phosphorus and potassium application on the yield of maize in the Savanna zone of Nigeria. Afr J Biotechnol, 2003; 2: 345-349

21. Kozakiewicz, Z. Aspergillus species on stored products Mycological Papers, 1989; 161: 1 C.A.B. International Mycological Institute, Kew, Surrey, UK.

22. Lacey, J., Pre- and post-harvest ecology of fungi causing spoilage of foods and other stored products. Journal of Applied Bacteriology Symposium Supplement, 1989; 11S-25S.

23. Liu, Z., Gao, J., and Yu, J. Aflatoxins in stored maize and rice grains in liaoning province china. J Stored Prod Res, 2006; 42: 468-479.

24. Logrieco A, Bottalico A, Mule G, Morelti A and Perrone G. Epidemiology of toxigenic fungi and their associated mycotoxins for some Mediterranean crops. European J Plant Pathol, 2003; 109; 645-667.

25. Magan, N., D. Aldred, R. Hope and D. Mitchell. Environmental factors and interactions with mycobiota of grain and grapes: effects on growth, deoxynivalenol and ochratoxin production by Fusarium culmorum and Aspergillus carbonarius. Toxins, 2010; 2: 353-366.

26. Moreno Cunha, E., Tironi García, G., Ono, M.A., Vizoni, E., Kawamura, O., Hirooka, E.Y., Sataque Ono, E.Y.Co-ocurrence of mycotoxins in corn samples from the Northern region of Paraná State, Brazil. Food Chemistry. 2009; 116: 220226.

27. Pacin, A.M., Bovier, E.C., González, H.L., Whitechurch, E.M., Martínez, E.J., Resnik, S. Fungal and fumonisins contamination in Argentine mayze (Zea mays L.) solo bags. Journal of Agricultural and Food Chemistry. 2009; 57 : 2778-2781.

28. Palumbo, J.D., T.L. O'keeffe and H.K. Abbas. Microbial interactions with mycotoxigenic fungi and mycotoxins Toxin Reviews, 2008; 27: 261- 
285.

29. Pitt, J. I. The Genus Penicillium and its Teleomorphic States, Eupenicillium and Talaromyces, 1979; pp: 634. Common Scientific Industrial Research Organization, Division of Food Research, North Ryde, NSW Australia, Academic Press, Inc. Ltd London .

30. RRI. International Rice Research Institute www. knowledgebank.irri.org/ppfm/storage/6.B.fungi.htm, 2006.

31. Samson, R. A., Hekstra, E. S., Frisvad, J. S. and Filtenborg, O. Introduction to Foodborne Fungi (4thed.), Centraalbureauvoor Schimmelcultures, 1995.

32. Samson, R. A., Hoeckstra, V. R., Frisvad, J. C and Filtenborg, O. Introduction to Food-Borne Fungi, 6th ed., 2002; p. 389 Centraalbureau voor Schimmelcultures Baarn Delft, The Netherlands.

33. Schuller, P. L., Van egmond, H. P. and Stoloff, L. Limits and regulations on mycotoxins. In: Naguib, K., Naguib, M. M Park, D. L., Pohland, A. E., 1983; pp.111-131. Proceedings of the International Symposium on Mycotoxins, 6-8 September 1981, Cairo, Egypt.

34. Shannon, G. M., Shotwell, O. L. and Kwolek, W. F. Extraction and thin-layer chromatography of aflatoxin B1 in mixed feeds. J Association Office of Analal Chem, 1983; 66: 582-586.

35. Takeda, Y., Isohata, E., Amono, R. and Uchiyama, M.Simultaneous extraction and fractionation and thin layer chromatographic determination of 14 mycotoxins in grains. J Association of Analyt Chem, 1979; 62: 573-578.

36. Torres AM, Roman B, Avila CM, Satovic Z, Rubiales D, Sillero JC, Cubero JI and Moreno M.Faba bean breeding for resistance against biotic stresses: Towards application of marker technology. Euphytica, 2006; 147: 67-80.

37. Varga, J. and Samson, R.A. Aspergillus in the Genomic Era Wageningen Academic Publishers, The Netherlands. 2008. 